Utah State University

DigitalCommons@USU

\title{
Herbivorous mammals along a montane sere: Community structure and energetics
}

Douglas C. Andersen

James A. MacMahon

Michael L. Wolfe

Follow this and additional works at: https://digitalcommons.usu.edu/aspen_bib

Part of the Forest Sciences Commons

\section{Recommended Citation}

Anderson, C. Douglas; MacMahon, James A.; Wolfe, Michael Wolfe. 1980. Herbivorous Mammals Along a Montane Sere: Community Structure and Energetics. Journal of Mammalogy 61(3): 500-519.

This Article is brought to you for free and open access by the Aspen Research at DigitalCommons@USU. It has been accepted for inclusion in Aspen Bibliography by an authorized administrator of DigitalCommons@USU. For more information, please contact

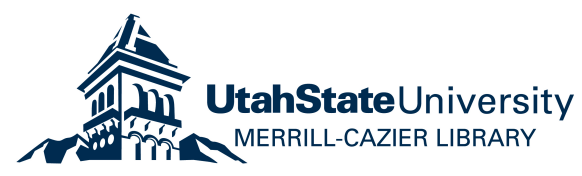




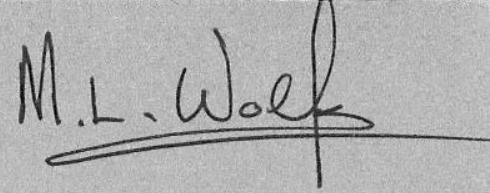

HERBIVOROUS MAMMALS ALONG A MONTANE SERE:

COMMUNITY STRUCTURE AND ENERGETICS

Douglas C. Andersen, James A. Macmahon, and Michael L. Wolfe

Made in United States of America

Reprinted from Journal of MAMMALOGY

Vol. 61, No. 3, August 1980

(C) 1980 The American Society of Mammalogists 


\title{
HERBIVOROUS MAMMALS ALONG A MONTANE SERE: COMMUNITY STRUCTURE AND ENERGETICS
}

\author{
Douglas C. Andersen, James A. Macmahon, and Michael L. Wolfe
}

\begin{abstract}
All common herbivorous mammals were censused along a successional gradient in northern Utah in order to assess some of the changes in ecosystem attributes predicted to occur by Odum (1969). Biomass (B) and energy flow [Production (P), Respiration $(\mathrm{R})$, and $\mathrm{P}+\mathrm{R}(\mathrm{E})$ ] through each of nine species in each of four seral stages (montane meadow, Populus-dominated forest, Abies-dominated forest, and Picea-dominated forest) were estimated. Tests of eight predicted trends were supportive in five cases ( $\mathrm{P} / \mathrm{R}$ ratio, $\mathrm{P} / \mathrm{B}$ ratio, $\mathrm{B} / \mathrm{E}$ ratio, net community production, and species richness), inconsistent in two cases (total organic matter and species evenness/general diversity) and ambiguous in one (size of organism). Community stability, as measured by changes in average community biomass between years of relatively normal and extremely low precipitation, increased with ecosystem maturity. Individual species, however, fluctuated greatly in biomass between the 2 years. Our results are consistent with the hypothesis that mammals are determinants of successional patterns only insofar as they affect plant colonization. However, a continuum probably exists between completely passive species and those that strongly influence successional patterns in plant communities through their effects on plant recruitment and/or mortality. Changes in the plant community in turn affect the composition of the herbivorous mammal community.
\end{abstract}

Ecological succession has been hypothesized by Odum (1969) to be an orderly, largely biotically controlled process culminating in a stabilized ecosystem in which maximum biomass is maintained per unit of energy flow. Other authors (e.g., Drury and Nisbet, 1973) have argued that most phenomena associated with succession can be understood as consequences of the differential colonization, growth, and survival of populations of species adapted to different positions along environmental gradients. In this view, succession need not be orderly in terms of biomass-energy flow relationships, and need not culminate in maximum biomass maintenance per unit of energy flow (see also Horn, 1974).

Odum (1969) predicted the direction of change in several of the collective properties or attributes of "developing" ecosystems. In this paper, we examine a portion of the mammalian component of a montane ecosystem in an effort to test those predictions concerning ecosystem structure and energetics that lend themselves to quantitative analysis (Table 1). Although variation in the distribution of mammals along successional gradients has been well documented (e.g., Hansen and Warnock, 1978; Hirth, 1959; Krefting and Ahlgren, 1974; Pearson, 1959; Sly, 1976; Verts, 1957; Wetzel, 1958), no study has considered more than a few of the species present in a quantitative manner, and none has dealt with the energetics of this taxocene. We consider four stages of a montane meadow to coniferous forest sere, and include in our analyses quantitative estimates of abundance, biomass, and energy flow for all common herbivorous mammals present.

Because our analyses rely on the output of a series of complex ecological models, we are unable to pursue a rigorous statistical evaluation of the patterns exhibited by the ecosystem attributes. We do, however, examine the robustness of our analyses (see Discussion). We are aware of the limitations of this methodology; at the present time this approach is the most biologically and economically tractable approach to the study of certain ecosystem attributes (see Humphreys, 1979; Levins, 1966; Wiens and Innis, 1974).

In this paper, we use "herbivore" in its broadest sense, to include species feeding 
on seeds, fruits, foliage, and/or belowground plant parts, as well as species whose diet is not exclusively plant material. Additionally, our use of the term "community" follows the definition of MacMahon et al. (1978), i.e., because all species we consider are, at least plausibly, linked by coevolutionary ties, they are members of the same community. Thus we refer to the assemblages of mammals discussed herein as herbivorous mammal communities.

Because the mammalian component of an ecosystem is only one of several affecting energy flow, acceptance or rejection of Odum's hypotheses based on the examination of this component alone would be premature. The data and results presented here will be combined elsewhere with those for birds, invertebrates, and primary producers in an effort to examine these and other predictions for the ecosystem as a whole (see MacMahon, in press, for preliminary results).

\section{METHODS}

\section{The Study Area}

We examined one of several seres found in the middle Rocky Mountains that progress from a subalpine or montane forb-dominated meadow to a climax forest dominated by Engelmann spruce (Picea engelmannii). The four seral stages recognized were: meadow, aspen (Populus tremuloides)-dominated forest, subalpine fir (Abies lasiocarpa)-dominated forest, and the climax spruce-dominated forest.

The study site was located in the Wasatch Mountains of northern Utah, in and adjacent to the Utah State University School Forest, Cache and Rich counties, $\sim 31 \mathrm{~km}$ NE Logan, Utah (elev. $2,570 \mathrm{~m}$ ). In this area, aspen typically forms narrow bands 20 to $40 \mathrm{~m}$ wide around the periphery of small meadows (0.3-10 ha, rarely larger). Larger expanses of subalpine fir-dominated forest grade into climax spruce-dominated forest. These seral stages form a mosaic with stages from other seres, notably lodgepole pine (Pinus contorta) forest and even-aged stands of subalpine fir established immediately after fire. Clumps of subalpine fir are commonly found in the interiors of meadows, and individuals or small groups of aspen, or even small openings that might be considered "meadow," can be found within fir and spruce forest. Thus, in each of the seral stages examined, vegetative components from adjacent stages probably exert some influence on the mammals present. For a detailed description of the site and its position in the context of succession in the Rocky Mountains, see Schimpf et al. (in press).

The School Forest has been subject to light to moderate grazing by both sheep and cattle for at least several decades. Although meadows were probably severely overgrazed in the early 1900 's, we assume that current meadow and forest conditions reflect those that would be present and affecting herbivorous mammals under pristine conditions.

\section{Density Estimates}

Fourteen species of herbivorous mammals (Table 2) were resident along the sere chosen for study: 11 rodents, a hare, and two ungulates. Three of the rodents were rare or localized in relatively small areas within a particular seral stage; these species were not considered in the analyses. Four independent live-trapping programs were conducted to obtain density estimates for the remaining rodent and lagomorph species, except Erethizon.

Mice, voles, and chipmunks.-Mice, voles, and chipmunks within each of the seral stages were censused three times during each of the summers of 1976 and 1977, and once each during late summer 1975 and early summer 1978. During each census, folding Sherman live-traps ( 8 by 9 by $23 \mathrm{~cm}$ ) baited with a peanut butter/oatmeal mix were run for 5 consecutive days. Traps were closed as they were checked in the morning, and reopened and rebaited in the evening. All captures were individually marked by toe clipping.

In 1975 and 1976, 10 replicate grids, each four by four stations with 7-m spacing were run in each seral stage. In 1977 and 1978, three replicate grids, each six by six with 15-m spacing were used. The increased grid size in 1977 and 1978 provided greater reliability in estimates of sampling area. For the 1976 (small grid) and 1977 (large grid) trapping seasons, home range estimates were calculated as described by Jennrich and Turner (1969) whenever an individual 
TABLE 1.-Trends to be expected in the successional development of ecosystems (from Odum, 1969).

\begin{tabular}{|c|c|c|}
\hline Ecosystem attributes & $\begin{array}{l}\text { Developmental } \\
\text { stages }\end{array}$ & Mature stages \\
\hline \multicolumn{3}{|c|}{ Community energetics } \\
\hline $\begin{array}{l}\text { Gross production/community } \\
\text { respiration ( } \mathrm{P} / \mathrm{R} \text { ratio) }\end{array}$ & $\begin{array}{l}\text { Greater or less } \\
\text { than } 1\end{array}$ & Approaches 1 \\
\hline $\begin{array}{l}\text { Gross production/standing } \\
\text { crop biomass (P/B ratio) }\end{array}$ & High & Low \\
\hline $\begin{array}{l}\text { Biomass supported/unit } \\
\text { energy flow (B/E ratio) }\end{array}$ & Low & High \\
\hline $\begin{array}{l}\text { Net community production } \\
\text { (yield) }\end{array}$ & High & Low \\
\hline \multicolumn{3}{|c|}{ Community structure } \\
\hline Total organic matter & Small & Large \\
\hline $\begin{array}{l}\text { Species diversity-variety } \\
\text { component }\end{array}$ & Low & High \\
\hline $\begin{array}{l}\text { Species diversity-equitability } \\
\text { component }\end{array}$ & Low & High \\
\hline \multicolumn{3}{|c|}{ Life history } \\
\hline Size of organism & Small & Large \\
\hline \multicolumn{3}{|c|}{ Selection pressure } \\
\hline Growth form & $\begin{array}{l}\text { For rapid growth } \\
\text { (" } r \text {-selection") }\end{array}$ & $\begin{array}{l}\text { For feedback control } \\
\text { ("K-selection") }\end{array}$ \\
\hline
\end{tabular}

was captured three or more times. The area sampled (grid plus surrounding area inhabited by individuals trapped on the grid) was estimated by adding the diameter of a circle of area equal to that of the pooled home range estimate for a given species to the side of the trapping grid and squaring the resulting length.

Eighteen estimates of the area sampled were generated from the 1976 data for Peromyscus. ANOVA indicated no significant differences among groupings based on seral stage and trapping period $(\mathrm{F}=0.33$, d.f. $=5,12)$. Thus the mean value $(0.31$ ha) was used to calculate Peromyscus densities. Similarly, 27 estimates for Tamias (=Eutamias) umbrinus were reduced to a single mean of 0.44 ha. This value is probably conservative because some animals were known to have traveled between grids. Sampling area estimates for T. umbrinus were also used for T. minimus. In the case of Clethrionomys, because of the low number of recaptures, the sampled area $(0.08$ ha) was considered to be the size of the trapping grid plus an outer band whose width was $1 / 2$ the trap spacing distance. The 1976 sampling area estimates for each species were applied to the 1975 population data.

Mean sampling areas calculated from the 1977 data were 2.41 ha for Peromyscus and 2.64 ha for T. umbrinus. Sampling areas for T. minimus and Clethrionomys were based on movements of individuals over the grids: one half the average distance moved was added to each side of the grid, resulting in values of 1.30 ha for T. minimus and 1.06 ha for Clethrionomys.

Pocket gophers.-Density estimates for pocket gophers (Thomomys talpoides) are based on the number of individuals having all or a portion of their home range within a 40 by $40-\mathrm{m}$ area. Three replicate plots were continuously monitored within each seral stage during the snow-free season; all gophers present within each plot were enumerated using live-traps similar to those of Baker and Williams (1972). Early summer (prebreeding) and late summer (postweaning, and probably postdispersal) population densities are used in the energy flow analyses.

Snowshoe hares.-To obtain estimates of the use of the individual seral stages, fecal pellets of snowshoe hares (Lepus americanus) were counted on a series of $2000.2 \mathrm{~m}^{2}$-plots distributed along 20 transects apportioned equally among the four stages. Counts were conducted imme- 
TABLE 2.-Characteristics of herbivorous mammals resident along a montane meadow-Engelmann spruce sere in northern Utah.

\begin{tabular}{|c|c|c|c|}
\hline Species & $\begin{array}{l}\text { Dietary } \\
\text { class }^{1}\end{array}$ & Life form ${ }^{2}$ & $\begin{array}{c}\text { Adult } \\
\text { approximate } \\
\text { weight }\end{array}$ \\
\hline Tamias $(=\text { Eutamias })^{3}$ minimus (least chipmunk) & G & $\mathrm{T}$ & $45 \mathrm{~g}$ \\
\hline T. umbrinus (Uinta chipmunk) & G & $\mathrm{T}$ & $65 \mathrm{~g}$ \\
\hline \multicolumn{4}{|l|}{ Spermophilus lateralis ${ }^{4}$} \\
\hline (golden-mantled ground squirrel) & G & $\mathrm{T}$ & $230 \mathrm{~g}$ \\
\hline Tamiasciurus hudsonicus (red squirrel) & G & A & $215 \mathrm{~g}$ \\
\hline Glaucomys sabrinus (northern flying squirrel) & $\mathrm{O}$ & A & $130 \mathrm{~g}$ \\
\hline Peromyscus maniculatus (deer mouse) & $\mathrm{O}$ & $\mathrm{T}$ & $21 \mathrm{~g}$ \\
\hline Neotoma cinerea 4 (bushy-tailed woodrat) & $\mathrm{O}$ & $\mathrm{T}$ & $380 \mathrm{~g}$ \\
\hline Zapus princeps ${ }^{4}$ (western jumping mouse) & $\mathrm{O}$ & $\mathrm{T}$ & $25 \mathrm{~g}$ \\
\hline Clethrionomys gapperi (Gapper's red-backed vole) & $\mathrm{F}$ & $\mathrm{T}$ & $23 \mathrm{~g}$ \\
\hline Thomomys talpoides (northern pocket gopher) & $\mathrm{F}^{5}$ & $\mathrm{~F}$ & $100 \mathrm{~g}$ \\
\hline Erethizon dorsatum (porcupine) & $\mathrm{F}$ & $\mathrm{A} / \mathrm{T}$ & $9.0 \mathrm{~kg}$ \\
\hline Lepus americanus (snowshoe hare) & $\mathrm{F}$ & $\mathrm{T}$ & $1.4 \mathrm{~kg}$ \\
\hline Odocoileus hemionus (mule deer) & $\mathrm{F}$ & $\mathrm{T}$ & $70 \mathrm{~kg}$ \\
\hline Cervus elaphus (wapiti) & $\mathrm{F}$ & $\mathrm{T}$ & $230 \mathrm{~kg}$ \\
\hline
\end{tabular}

${ }^{1} \mathrm{G}=$ Granivore; $\mathrm{F}=$ Foliovore $; \mathrm{O}=$ Omnivore. ${ }^{2} \mathrm{~T}=$ Terrestrial; $\mathrm{A}=$ Arboreal; $\mathrm{F}=$ Fossorial. ${ }^{3}$ Nomenclature after Nadler et al. (1977). ${ }^{4}$ Rare in study area. ${ }^{5}$ Includes belowground plant parts.

diately after snowmelt, and again in late summer to provide indications of seasonal changes in usage. Analysis of the pellet data for 1976 and 1977 indicated no significant differences (MannWhitney U-test, $P>0.05$ ) in use of fir and spruce seral stages; use of meadows and aspen stands was negligible.

Snowshoe hares were trapped in December 1975, April and December 1976, August and October 1977, and April 1978, using Tomahawk double-door live-traps baited with apples or alfalfa hay. Both grid size and location were varied between trapping sessions in attempts to increase trapping success and eliminate logistical problems. In all trapping sessions, grids occupied large areas (16-40 ha) that overlapped both fir and spruce seral stages; aspen and meadow were not trapped. Traps were run until population estimates stabilized (8-13 days). The final density estimates used in the analyses are based on our trapping data and additional demographic information from a study in a nearby area (Dolbeer and Clark, 1975).

Tree squirrels.-Attempts to census red squirrels (Tamiasciurus hudsonicus) were made in August and September 1976, in April, July, and August 1977, and in July 1978. Early attempts relying on placement of Tomahawk double-door live-traps at middens were hampered by a high trap mortality; in 1977 an extremely productive cone crop reduced trap response to near zero. Line transect methods (Kelker, 1945; Eberhardt, 1978) were employed, with some success, in an effort to increase the reliability of our estimates. The density estimates used in the energetics program are based on the combined results of both sampling methods, personal observations of midden densities and use, and estimates of numbers based on recruitment and mortality rates reported by other workers in similar habitats (Kemp and Keith, 1970; Rusch and Reeder, 1978). No differences in squirrel densities between spruce and fir seral stages could be detected.

Continuous operation of the Tomahawk traps allowed us to estimate the densities of nocturnal northern flying squirrels (Glaucomys sabrinus) concurrently with the diurnal red squirrels. Estimates made in this manner were averaged with those obtained from captures of Glaucomys during operation of the "mouse and chipmunk" grids.

Porcupine.-Porcupine (Erethizon dorsatum) were commonly observed within the study area, but no effort was made to determine actual abundances. Densities in various montane mixedconifer (generally pine-fir) forests range from 4 to $16 \mathrm{~km}^{-2}$ (Smith, 1977 and references therein). The subclimax fir seral stage probably supports a higher density than the climax spruce, due to the apparent preference shown by porcupines toward younger trees as a food source (references in Smith, 1977). Populations subjectively appear stable. We have arbitrarily selected $10 \mathrm{~km}^{-2}$ and $5 \mathrm{~km}^{-2}$ as reasonable estimates of densities within the fir and spruce seral stages, respectively, during winter. Meadow and aspen seral stages were used only during the summer months. 
TABLE 3.-Input values for energetics calculations. Species not included here had all parameter values estimated from regression equations as in French et al. (1976).

\begin{tabular}{|c|c|c|c|}
\hline \multirow[b]{2}{*}{ Species } & \multicolumn{2}{|c|}{$\begin{array}{l}\mathrm{ADMR}^{1}=\mathrm{aW}^{\mathrm{b}} \\
\left(\mathrm{kcal} \mathrm{g}^{-1} \text { day }^{-1}\right)\end{array}$} & \multirow{2}{*}{$\begin{array}{c}\text { Conduction } \\
\left(\mathrm{kcal} \mathrm{g}^{-1} \text { day }^{-1}{ }^{\circ} \mathrm{C}^{-1}\right)\end{array}$} \\
\hline & a & $\mathrm{b}$ & \\
\hline Thomomys talpoides & $3.135^{2}$ & 1 & $0.0092^{3}$ \\
\hline Tamiasciurus hudsonicus & $2.615^{4}$ & & $0.0098(\mathrm{~S})^{5}$ \\
\hline Lepus americanus & $4.100^{6}$ & & $\begin{array}{l}0.0086(W) \\
0.0033(\mathrm{~S})^{7}\end{array}$ \\
\hline Erethizon dorsatum & $0.5875^{8}$ & $-0.25^{8}$ & $0.0026(W)$ \\
\hline
\end{tabular}

${ }^{1}$ Equation from French et al. (1976) used as standard, with $\mathrm{a}=2.297, \mathrm{~b}=-0.5$ and conduction $=0.089 \mathrm{~W}^{-0.46}$, in cases where specific values not tabulated. ${ }^{2}$ Based on a cost of $0.749 \mathrm{kcal}^{-1}$ day ${ }^{-1}$ for activity outside the nest (Andersen, unpubl.), resting metabolic rate (RMR) at thermoneutrality of $0.1532 \mathrm{kcal} \mathrm{g}^{-1} \mathrm{~g}_{\text {day }}^{-1}$ (Gettinger, 1975), and activity budget of $25 \%$ of time active inside nest at thermoneutrality (cost $=1.5 \mathrm{RMR}$ ), $25 \%$ active outside nest, and $50 \%$ inactive in nest at thermoneutrality. ${ }^{3} \mathrm{Gettinger}$ (1975). ${ }^{4}$ From French et al. (1976) after Grodzinski $(1966,1971) .{ }^{5}$ Irving et al. (1955). ${ }^{6}$ Based on $116 \mathrm{~W}^{+0.75} \mathrm{kcal} \mathrm{day}^{-1}$ minimum daily metabolic energy requirement for $1,500 \mathrm{~g}$ hare [Holter et al. (1974)]. ${ }^{7}$ Hart et al. (1965). ${ }^{8}$ Based on activity $50 \%$ of time at
a cost $=2 \mathrm{RMR}$, with $\mathrm{RMR}=3.4 \mathrm{~W}^{-0.25} \mathrm{ccO}_{2} \mathrm{~g}^{-1} \mathrm{hr}^{-1}$ [Kleiber (1961)].

We have selected summer densities of 3 (meadow), 5 (aspen), 8 (fir), and 5 (spruce) $\mathrm{km}^{-2}$ as estimates for use in the energetic analyses.

Ungulates.-Mule deer (Odocoileus hemionus), were relatively common within the study area during the snow-free season, while wapiti (Cervus elaphus) occurred infrequently. Moose (Alces alces) were very rare. No ungulates used the study area in winter. An attempt to quantify patterns of use of the four seral stages by these ungulates through fecal pellet counts was unsuccessful. They are therefore not considered in any of our quantitative comparisons among the seral stages. To gain some indication of the contribution of these large mammals to the total community biomass within the sere, and thus an idea of their potential contribution to the various seral stages, summer densities were estimated from hunter harvest figures and herd composition data (deer) or winter aerial survey data (wapiti) from the Utah Division of Wildlife Resources (UDWR, 1977). The contribution of moose was assumed to be negligible. The summer density estimates were then combined with biomass values derived from the literature, and average daily biomass was computed over arbitrarily defined periods of seasonal occupancy of the study area by deer and wapiti of 150 and 180 days, respectively.

\section{Biomass and Productivity}

All individuals were weighed and aged (as immature or adult) at each capture, providing data from which average age-specific weights were determined for all species trapped. Porcupines were assumed to weigh $9 \mathrm{~kg}$ as adults, and $2 \mathrm{~kg}$ as juveniles (based on Taylor, 1935; Woods, 1973 and references therein).

Sex ratios were assumed 1:1 for all species. The proportion of females breeding, the number of litters, and the length of the breeding season were determined from the trapping data or from the literature. All production estimates in the analysis are derived from the energetics model described below.

\section{Energetics Computation Methods}

A modified form of the small mammal energetics model developed by French et al. (1976) was used to estimate respiration, production, and consumption within each of the four seral stages. Briefly, the program calculates an average daily weight-specific metabolic rate (ADMR) for a species age class, given the average weight of an individual within that age class. The ADMR is then modified for thermoregulation and/or reproduction (in females), multiplied by total biomass within the age class, and summed over age classes to arrive at a daily energy budget (DEB) for that species. Daily biomass is linearly interpolated between sampling dates. Production is calculated from the species' DEB summed over a year, using the regression equation of Grodzinski and French (cited by French et al., 1976). Consumption is then calculated as the (daily) DEB plus production (prorated on a daily basis over the length of the breeding season) divided by the species' assimilation efficiency. 
TABLE 4.-Density estimates (individuals/ha) for Clethrionomys gapperi (CLEGAP), Tamias minimus (TAMMIN), T. umbrinus (TAMUMB), Glaucomys sabrinus (GLASAB), and Peromyscus maniculatus (PERMAN) for early $(E)$, middle $(M)$, and late $(L)$ summer, 1975-1978, and early and late summer densities of Thomomys talpoides (THOTAL) for the same period.

\begin{tabular}{|c|c|c|c|c|c|c|c|c|}
\hline \multirow{2}{*}{$\begin{array}{l}\text { Seral stages } \\
\text { and species }\end{array}$} & \multirow{2}{*}{$\begin{array}{c}1975 \\
\mathrm{~L}\end{array}$} & \multicolumn{3}{|c|}{1976} & \multicolumn{3}{|c|}{1977} & \multirow{2}{*}{$\frac{1978}{\mathrm{E}}$} \\
\hline & & $\mathrm{E}$ & M & $\mathrm{L}$ & $\mathrm{E}$ & $\mathrm{M}$ & $\mathrm{L}$ & \\
\hline \multicolumn{9}{|l|}{ Meadow } \\
\hline \multicolumn{9}{|l|}{ CLEGAP } \\
\hline TAMMIN & 0.3 & 0.3 & & 0.8 & 1.8 & 1.0 & 5.7 & 1.3 \\
\hline TAMUMB & 2.0 & 7.0 & 2.7 & 2.7 & 4.5 & 1.2 & 0.7 & 2.3 \\
\hline \multicolumn{9}{|l|}{ GLASAB } \\
\hline PERMAN & 21.3 & 8.7 & 15.8 & 16.1 & 6.0 & 6.1 & 6.3 & 4.1 \\
\hline THOTAL & 25.0 & 25.0 & & 54.4 & 16.9 & & 14.4 & 5.3 \\
\hline \multicolumn{9}{|l|}{ Aspen } \\
\hline CLEGAP & 0.8 & & 3.7 & & 1.3 & 0.9 & 1.3 & 0.9 \\
\hline TAMMIN & 1.1 & & 2.2 & 0.8 & 4.6 & 8.9 & 2.1 & 1.0 \\
\hline TAMUMB & 3.9 & 11.4 & 8.9 & 3.0 & 2.0 & 2.1 & 0.8 & 1.5 \\
\hline GLASAB & 1.8 & 1.0 & 1.0 & & 0.7 & 0.2 & 0.5 & 0.5 \\
\hline PERMAN & 5.2 & 7.4 & 14.8 & 3.9 & 1.8 & 3.1 & 3.1 & 0.8 \\
\hline THOTAL & 14.4 & 14.4 & & 33.1 & 6.2 & & 4.4 & 2.1 \\
\hline \multicolumn{9}{|l|}{ Fir } \\
\hline CLEGAP & 1.2 & 1.7 & & 1.7 & 1.6 & 0.9 & 1.3 & 1.9 \\
\hline TAMMIN & & 0.3 & & & & 0.8 & & \\
\hline TAMUMB & 7.0 & 17.0 & 5.7 & 6.6 & 8.4 & 3.8 & 2.1 & 2.3 \\
\hline GLASAB & 5.8 & 2.0 & 2.0 & 1.5 & 2.4 & 1.2 & 2.1 & 1.6 \\
\hline PERMAN & 3.2 & 2.3 & 2.9 & 8.1 & 4.6 & 3.6 & 3.6 & 2.5 \\
\hline THOTAL & 6.2 & 6.2 & & 12.5 & & & & \\
\hline \multicolumn{9}{|l|}{ Spruce } \\
\hline CLEGAP & 2.5 & 1.2 & & 0.4 & & 1.3 & 1.3 & 1.2 \\
\hline TAMMIN & & & & & & 0.8 & 0.2 & 1.3 \\
\hline TAMUMB & 9.5 & 10.9 & 6.1 & 4.3 & 6.3 & 4.1 & 1.2 & 3.9 \\
\hline GLASAB & 1.8 & 0.5 & 0.2 & 1.0 & 2.1 & 1.4 & 1.4 & 0.5 \\
\hline PERMAN & 5.5 & 7.1 & 5.5 & 1.9 & 3.3 & 3.9 & 4.2 & 2.7 \\
\hline THOTAL & & & & 4.4 & & & & 0.4 \\
\hline
\end{tabular}

French et al. (1976) developed equations relating ADMR and conductance to weight for estimation of DEB in their model. We modified the program to allow the optional input of other values for use in calculating ADMR and conductance in lieu of internally computed values. This was necessary because discrepancies existed between the internally computed values and values found in, or calculated from, energetic studies of the larger mammals we considered. Input values of parameters used to calculate DEBs are given in Table 3. Assimilation efficiencies for all species considered in this study (dietary classes are listed in Table 2) are based on table 5 in French et al. (1976).

\section{Environmental Parameters}

During the snow-free season the environmental temperatures experienced by mammals active aboveground were assumed to equal air temperatures measured $\sim 3 \mathrm{~m}$ above the ground surface. Air temperatures in a meadow and in a stand of mixed spruce and subalpine fir were continuously monitored using hygrothermographs placed in standard weather boxes. Because both nocturnal and diurnal species were considered in the energetics analyses, temperatures were transcribed for all even hours between 0200 and $2400 \mathrm{~h}$, and a weekly estimate of "night" temperature obtained as the minimum bihourly average. That is, all 0600-h measurements for a given week were averaged, compared to the 0400-h average, the 0200 -h average, etc., and the minimum taken as representing the "night" temperature experienced by surface-dwelling nocturnal species. "Day" temperatures were calculated as the average of the weekly mean temperature 
TABLE 5.-Density (individuals/ha) estimates for snowshoe hares (Lepus americanus) and red squirrels (Tamiasciurus hudsonicus) used in estimation of population energy flow. Estimates were applied equally to spruce and fir seral stages.

\begin{tabular}{|c|c|c|c|c|c|c|c|c|c|c|c|}
\hline \multirow[b]{2}{*}{ Species } & \multirow{2}{*}{$\begin{array}{l}1975 \\
\text { Dec }\end{array}$} & \multicolumn{5}{|c|}{1976} & \multicolumn{3}{|c|}{1977} & \multicolumn{2}{|c|}{1978} \\
\hline & & Apr & Jul & Aug & Sep & Dec & Apr & Jul & Aug & Jan & May \\
\hline Lepus & 0.5 & 0.41 & 1.0 & & & 0.5 & 0.3 & 1.8 & & & 2.7 \\
\hline Tamiasciurus & 1.0 & & & 2.6 & 0.8 & & 0.2 & & 1.2 & 1.0 & \\
\hline
\end{tabular}

(the average of all transcribed measurements) and the maximum bihourly average (calculated analogously to the minimum bihourly average as described above).

Soil temperatures, used in estimating Thomomys energy budgets, were obtained using a series of 3 to 10 copper-constantan thermocouples placed $15 \mathrm{~cm}$ below the soil surface in each of meadow, aspen, and coniferous forest. Temperatures were measured every 1 to $2 \mathrm{~h}$ for $\sim 24 \mathrm{~h}$ at 2 to 4 week intervals, and these intensive measurements were used to adjust extensive single measurements taken 1 to 2 times each week for daily variation. Subnivial temperatures $(5 \mathrm{~cm}$ above soil surface) were obtained using thermocouples placed in the same localities used for obtaining soil temperatures.

\section{RESUlTS}

Density and biomass.-Density estimates for the eight species of mammals trapped within the U.S.U. School Forest are presented in Tables 4 and 5. The values for Peromyscus, Clethrionomys, and the two species of Tamias (Table 4) are based on minimum numbers alive at the time of sampling, and thus constitute minimum estimates. Thomomys (Table 4) reached the highest population densities: more than 50/ ha in late summer of 1976. Clethrionomys was consistently rare, with typical densities of 1 to 2 per ha.

Total biomass or standing crop varied considerably both between seral stages and between years (Fig. 1). The relative contributions to total biomass by the component species also varied both between seral stages and years (Table 6), reflecting the general change in small rodent densities between 1976 and 1977 (Table 4).

Average summer ungulate densities on the School Forest during 1976 and 1977 were approximately 0.11 deer and 0.02 wapiti per ha. Corollary estimates of average daily biomass are 0.23 and $0.12 \mathrm{~g} / \mathrm{m}^{2}$, respectively. Comparison of these values with those tabulated for other component species (Table 6) reveals that the contribution of these ungulates to the total mammalian herbivore biomass across the sere is at least comparable to that of all other species combined.

Energy flow.-Lacking a means of empirically partitioning ungulate use of the School Forest among the four seral stages, we are forced to exclude them from the energetic analyses. Thus, the following results concerning energy flow patterns along the successional gradient are based only on the nine common small- and mediumsized mammals (Table 2).

Total energy flow through the remaining herbivorous mammals within each of the seral stages is presented in Fig. 2. Maximum consumption, $125 \mathrm{kcal} \mathrm{m}^{-2} \mathrm{yr}^{-1}$, occurred in the meadow during 1976, whereas the lowest value, $26 \mathrm{kcal} \mathrm{m}^{-2} \mathrm{yr}^{-1}$, was recorded in the spruce during 1977. Consumption fell progressively with increasing successional stage in 1976. In 1977 the middle seral stages, aspen and fir, were reversed in rank, although the $\sim 6 \%$ separation is of doubtful significance.

Individual contributions to consumption and energy flow within the seral stages during 1976 reflected the biomass contributions of the respective species, and were dominated by Thomomys in all but the climax spruce (Table 7). Tamias umbrinus and Lepus americanus each exceeded Thomomys in consumption, respiration, and 


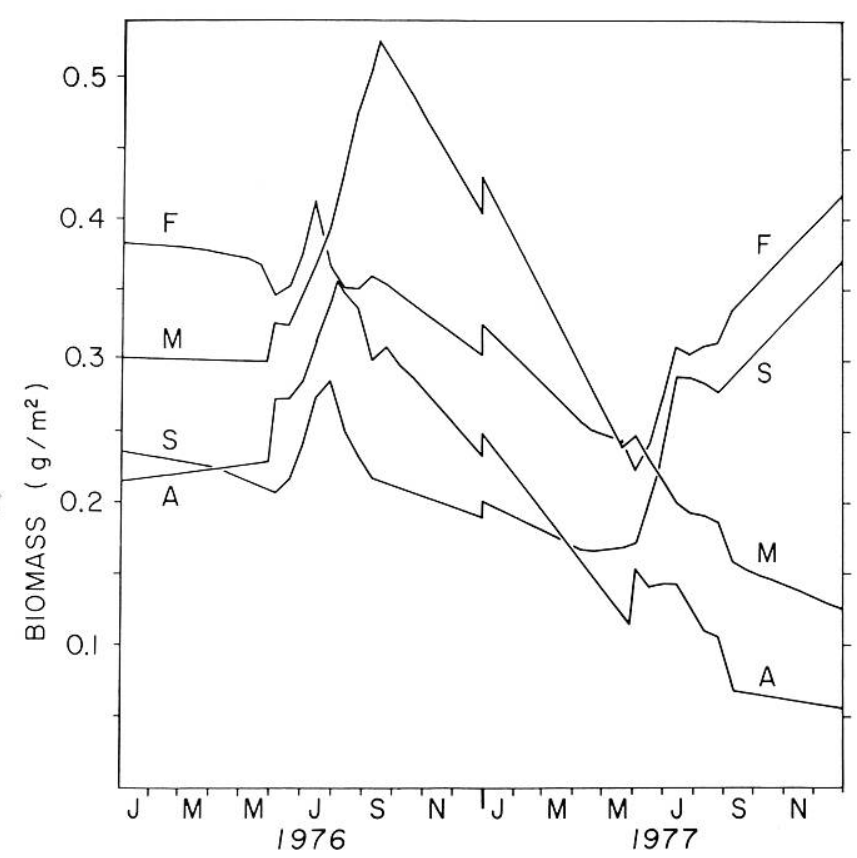

FIG. 1.-Total biomass of herbivorous mammals (excluding ungulates) in each of four seral stages, meadow (M), aspen (A), fir (F), and spruce (S), during 1976 and 1977. The discontinuity at 1 January 1977 is an artifact of the model: individuals overwintering as subadults were reclassified as adults on that date.

production in the spruce, both in 1976 and 1977. Pocket gophers retained dominance in the early seral stages in 1977, while T. umbrinus became dominant in the fir, and Lepus dominated all other species in terms of energy flow and consumption in the spruce.

Successional trends.-Patterns in "community energetics" are shown in Fig. 3. Both the production/respiration ratio $(\mathrm{P} / \mathrm{R})$ and the production/biomass ratio $(\mathrm{P} / \mathrm{B})$ decreased with developmental age of the site, while the biomass supported per unit of

TABLE 6.-Contributions of the component mammals to total biomass within the four seral stages, meadow $(M)$, aspen $(A)$, fir $(F)$, and spruce $(S)$. Tabulated values are average daily biomass $\left(\times 10^{-3} \mathrm{~g} \mathrm{~m}^{-2}\right)(\%$ contribution $)$.

\begin{tabular}{|c|c|c|c|c|c|c|c|c|}
\hline \multirow[b]{3}{*}{ Species } & \multicolumn{4}{|c|}{1976} & \multicolumn{4}{|c|}{1977} \\
\hline & \multicolumn{4}{|c|}{ Seral stage } & \multicolumn{4}{|c|}{ Seral stage } \\
\hline & M & A & $\mathrm{F}$ & $\mathrm{S}$ & M & A & $\mathrm{F}$ & $\mathrm{S}$ \\
\hline Thomomys talpoides & $312.7(83)$ & $182.8(70)$ & $72.6(20)$ & $15.1(7)$ & $190.6(81)$ & $85.9(67)$ & $16.4(5)$ & $6.0(2)$ \\
\hline Tamias umbrinus & $29.1(8)$ & $42.9(16)$ & $72.1(20)$ & $53.2(24)$ & $16.2(7)$ & $10.4(8)$ & $32.9(11)$ & $25.5(10)$ \\
\hline Peromyscus maniculatus & $27.0(7)$ & $10.5(4)$ & $9.1(2)$ & $8.5(4)$ & $12.6(5)$ & $4.3(3)$ & $7.5(2)$ & $5.6(2)$ \\
\hline Erethizon dorsatum & $6.0(2)$ & $10.0(4)$ & $77.9(22)$ & $41.0(18)$ & $6.0(2)$ & $10.0(8)$ & $77.9(25)$ & $41.0(17)$ \\
\hline Tamias minimus & $2.2(1)$ & $4.0(2)$ & $0.5(0)$ & & $10.1(4)$ & $10.2(8)$ & $0.3(0)$ & $0.7(0)$ \\
\hline Glaucomys sabrinus & & $11.0(4)$ & $32.6(9)$ & $11.4(5)$ & & $6.3(5)$ & $24.8(8)$ & $18.3(8)$ \\
\hline Clethrionomys gapperi & & $1.2(1)$ & $3.1(1)$ & $2.2(1)$ & & $1.6(1)$ & $2.7(1)$ & $0.9(0)$ \\
\hline Lepus americanus & & & $65.8(18)$ & $65.8(30)$ & & & $133.1(43)$ & $133.3(54)$ \\
\hline Tamiasciurus hudsonicus & & & $25.6(7)$ & $25.6(12)$ & & & $14.3(5)$ & $14.3(6)$ \\
\hline TOTALS & 377.0 & 262.4 & 359.3 & 222.8 & 235.5 & 128.7 & 309.9 & 245.4 \\
\hline
\end{tabular}




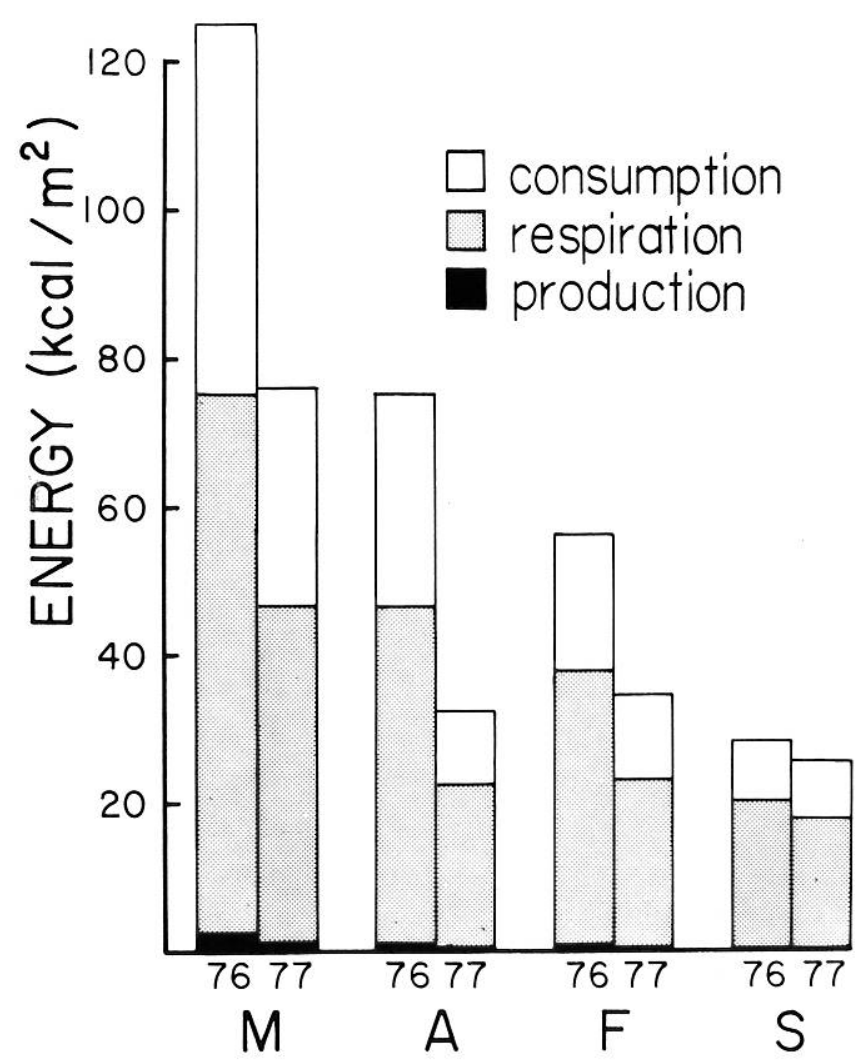

FIG. 2.-Annual community energy transfers for 1976 and 1977. Values are superimposed for each year-seral stage combination, e.g., in the meadow in 1976, values for consumption, respiration, and production were 125,75 , and $2.4 \mathrm{kcal} \mathrm{m}^{-2}$, respectively.

energy flow (B/E) increased. Secondary production was highest in the meadow and progressively decreased to lowest values in the climax spruce forest.

Patterns in attributes related to "community structure" are shown in Fig. 4. Using the average daily biomass (standing crop) within each of the seral stages as a measure of organic matter present, no consistent trend is evident along the successional gradient. Species richness increased from a low of six species in the meadow to a high of nine species considered on the basis of our trapping data to be permanent residents within the fir and spruce seral stages (Fig. 4). We used the Shannon-Wiener index, $\mathrm{H}^{\prime}$, to provide a general measure of diversity, and $\mathrm{J}^{\prime}\left(\mathrm{H}^{\prime} / \mathrm{H}^{\prime}{ }_{\max }\right)$ as a measure of equitability within each of the seral stages. Because all of the species we consider are to some degree competitors and one porcupine hardly seems equivalent to one pocket gopher, we selected average biomass rather than numbers of individuals as the unit of measure.

No obvious trend was evident in the size of organisms occupying the various seral stages. The largest herbivores considered in this study, excluding ungulates and the ubiquitous porcupine, are the red squirrel and the snowshoe hare, species found only in the more mature (coniferous) seral stages (Table 2). If ungulates are considered, however, the trend could be reversed, because they frequent earlier seral stages. 
TABLE 7.-Contributions of the component mammals to total annual respiration, production, and consumption within the meadow $(M)$, aspen $(A)$, fir $(F)$, and spruce $(S)$ seral stages in 1976 (upper) and 1977 (lower). All values tabulated have units $\left(\times 10^{-1} \mathrm{kcal} \mathrm{m}^{-2}\right)$.

\begin{tabular}{|c|c|c|c|c|c|c|c|c|c|c|c|c|}
\hline \multirow[b]{2}{*}{ Species } & \multicolumn{4}{|c|}{ Respiration } & \multicolumn{4}{|c|}{ Production } & \multicolumn{4}{|c|}{ Consumption } \\
\hline & M & A & $\mathrm{F}$ & $\mathrm{S}$ & M & A & $\mathrm{F}$ & $\mathrm{S}$ & M & A & $\mathrm{F}$ & S \\
\hline Thomomys talpoides & 639.5 & 363.8 & 146.0 & 29.6 & 21.7 & 11.4 & 4.04 & .66 & $1,101.9$ & 625.3 & 250.0 & 50.5 \\
\hline Tamias umbrinus & 29.6 & 44.6 & 73.3 & 53.6 & .66 & 1.05 & 1.85 & 1.30 & 34.4 & 51.9 & 85.4 & 62.4 \\
\hline Peromyscus maniculatus & 77.0 & 30.9 & 25.2 & 24.6 & 1.95 & .69 & .55 & .53 & 108.2 & 43.3 & 35.3 & 34.4 \\
\hline Erethizon dorsatum & 1.5 & 2.5 & 21.1 & 11.0 & .02 & .04 & .45 & .21 & 2.3 & 3.8 & 33.1 & 17.3 \\
\hline Tamias minimus & 3.1 & 5.5 & 0.6 & & .05 & .10 & .01 & & 3.5 & 6.3 & .7 & \\
\hline Glaucomys sabrinus & & 14.1 & 42.7 & 15.6 & & .28 & 1.00 & .32 & & 19.7 & 59.8 & 21.7 \\
\hline Clethrionomys gapperi & & 3.2 & 9.2 & 6.4 & & .05 & .17 & .12 & & 5.0 & 14.4 & 10.1 \\
\hline Lepus americanus & & & 34.3 & 34.3 & & & .78 & .78 & & & 54.0 & 54.0 \\
\hline Tamiasciurus hudsonicus & & & 29.7 & 29.7 & & & .66 & .66 & & & 34.5 & 34.5 \\
\hline TOTALS & 750.7 & 464.6 & 382.1 & 204.9 & 24.34 & 13.62 & 9.51 & 4.58 & $1,250.4$ & 755.4 & 567.4 & 285.0 \\
\hline Thomomys talpoides & 390.1 & 170.1 & 34.6 & 12.8 & 12.3 & 4.81 & .79 & .25 & 670.7 & 291.4 & 59.0 & 21.7 \\
\hline Tamias umbrinus & 17.8 & 11.7 & 36.9 & 28.8 & .37 & .23 & .85 & .64 & 20.7 & 13.5 & 42.9 & 33.5 \\
\hline Peromyscus maniculatus & 38.4 & 12.9 & 22.7 & 17.3 & .89 & .26 & .49 & .35 & 53.8 & 18.1 & 31.7 & 24.2 \\
\hline Erethizon dorsatum & 1.5 & 2.5 & 21.1 & 11.1 & .02 & .04 & .45 & .22 & 2.3 & 3.8 & 33.2 & 17.3 \\
\hline Tamias minimus & 16.4 & 15.9 & .5 & 1.1 & .34 & .33 & .01 & .02 & 19.0 & 18.5 & 6 & 1.3 \\
\hline Glaucomys sabrinus & & 6.2 & 25.1 & 18.9 & & .11 & .54 & .04 & & 8.6 & 35.2 & 26.4 \\
\hline Clethrionomys gapperi & & 5.0 & 8.5 & 2.9 & & .09 & .16 & .05 & & 7.7 & 13.4 & 4.6 \\
\hline Lepus americanus & & & 70.1 & 70.1 & & & 1.76 & 1.76 & & & 110.6 & 110.6 \\
\hline Tamiasciurus hudsonicus & & & 17.5 & 17.5 & & & .36 & .36 & & & 20.3 & 20.3 \\
\hline TOTALS & 464.2 & 224.2 & 237.1 & 180.5 & 13.96 & 5.85 & 5.40 & 4.04 & 766.6 & 361.7 & 346.8 & 259.9 \\
\hline
\end{tabular}

\section{DISCUSSION}

Density estimates and precision of the energetics model.-French et al. (1976) analyzed the basic model used in this study for relative sensitivity and found that the model output was most sensitive to assimilation efficiency and biomass estimates. Our biomass estimates are subject to error derived from several sources (e.g., mean weights, the proportions in various age classes), but the most important contributors to error are probably the estimates of population size. Population estimates for Thomomys, obtained by enumeration on replicate plots, had $95 \%$ confidence intervals that ranged from $\pm 10 \%$ of the mean for meadow, where populations were largest, to $\sim 100 \%$ of the mean in the climax Engelmann spruce-dominated forest, where individuals were rare and showed a contagious distribution. Estimates of the population sizes of Tamias umbrinus based on the Jackknife estimator (Burnham and Overton, 1969) indicated that the actual values may have been as much as $100 \%$ higher than the values (minimum number alive) used in the energy flow analyses. Jackknife estimates, which generally were comparable to estimates based on several other estimators, suggested actual values for most of the small mammals to be $\sim 25 \%$ higher than those used.

To assess the effects of error in our biomass estimates on the trends in community energetics over the sere, density values for seven of the nine species present were modified within ranges considered representative of $95 \%$ confidence intervals around the species' true density (Table 8 ). The trends in production, biomass, $\mathrm{P} / \mathrm{R}, \mathrm{P} / \mathrm{B}$, and $\mathrm{P} / \mathrm{E}$ based on the modified values were then compared to the trends based on results from the original density estimates. Although some variation in pattern is evident, such as $\mathrm{B} / \mathrm{E}$ reaching highest values in the fir as opposed to the spruce seral stage in trial 6 (Fig. 5), the overall trend in each case is the same as that found on the basis of the original data set. In trial 7 (Table 8, Fig. 5), densities were intentionally modified to counter the pattern of bias we consider most likely to have occurred. The resulting trends are identical to those produced by the original data set. 

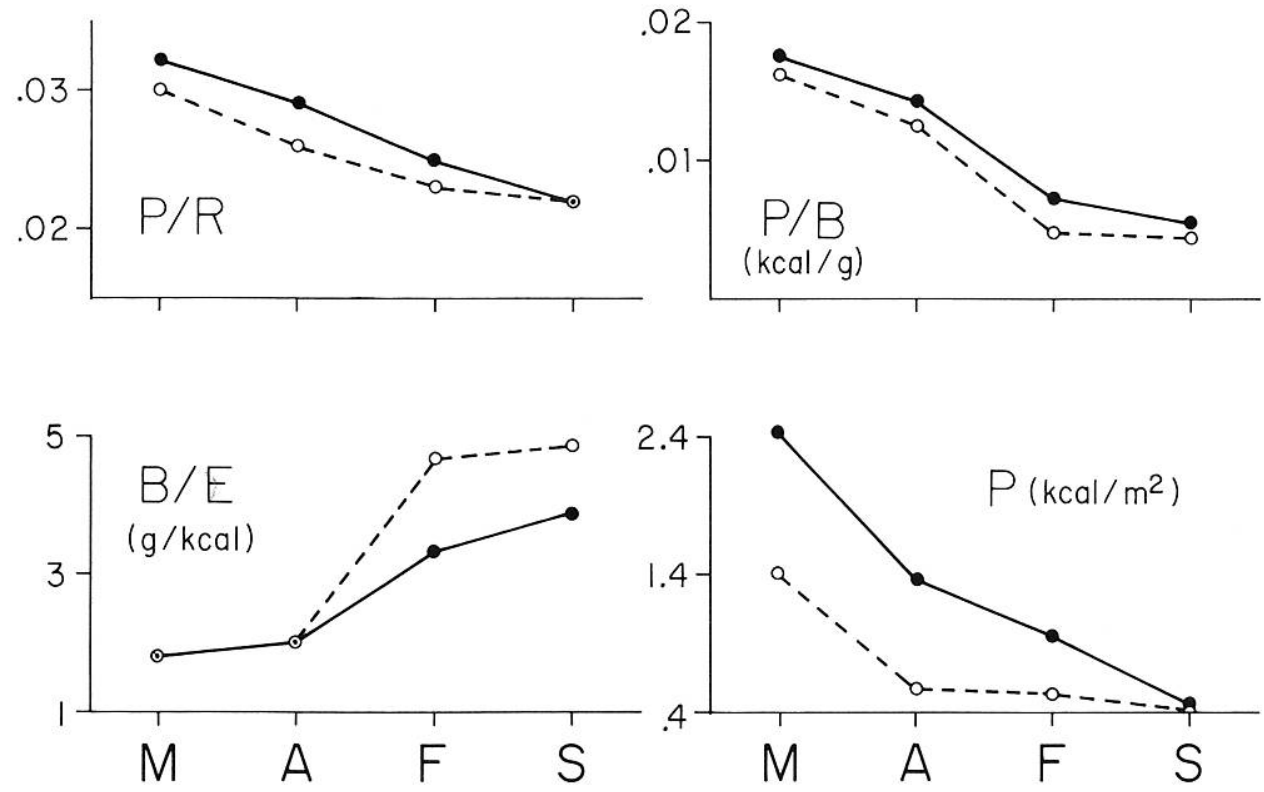

FIG. 3.-Changes in community attributes between the four seral stages, meadow (M), aspen $(\mathrm{A})$, fir $(\mathrm{F})$, and spruce $(\mathrm{S})$. Energy flow $(\mathrm{E})=$ production $(\mathrm{P})+$ respiration $(\mathrm{R})$. Solid lines and circles represent 1976, broken lines and open circles 1977; biomass is abbreviated as B.

Odum's ecosystem attributes.-In discussing gross production, Odum (1969) referred to the total (gross) photosynthesis taking place within the ecosystem, and thus our use of secondary production in the $\mathrm{P} / \mathrm{R}$ ratio is an inappropriate test of the predicted trend (Table 1). Odum based this prediction on the argument that the energy cost of maintenance will, over time, approach the total amount of energy fixed in the ecosystem; in the climax stage there will be no net energy (biomass) accumulation or deficit in the ecosystem (see also Odum, 1971:252). To attempt to provide an analogous argument regarding the approach of the mammalian secondary production/respiration ratio toward a fixed value such as 1.0 is impossible. The " $\mathrm{P} / \mathrm{R}$ " ratio as used herein reflects the relative contributions of respiration and secondary production to total energy flow. Because these two categories comprise the total assimilated energy, the ratio reflects the relative apportionment of available energy into secondary production (reproduction and growth) and into maintenance. In terms of " $r$ " and " $\mathrm{K}$ " strategies, it would be expected that the former includes energy input into such tangible (energy expensive) reproductive features as rapid growth and large litter sizes, i.e., features leading to high input into secondary production relative to " $\mathrm{K}$ " type strategies. Odum (1969) considered early successional stages to contain " $r$ " strategists, whereas the mature stages contain " $K$ " strategists (Table 1 ). The $P / R$ ratios found in this study (Fig. 3) are consistent with this prediction.

Odum suggested the $\mathrm{P} / \mathrm{B}$ ratio should decrease with increasing ecosystem maturity (Table 1). His arguments follow those presented for P/R above, i.e., that there will be a net accumulation of matter (energy) in an ecosystem in which total (gross) photosynthesis exceeds total ecosystem-wide respiration. Greater amounts of living biomass lead to higher levels of respiration, and thus $\mathrm{P} / \mathrm{B}$ should reflect $\mathrm{P} / \mathrm{R}$, with minimum values when the latter reaches 1 . 
A.

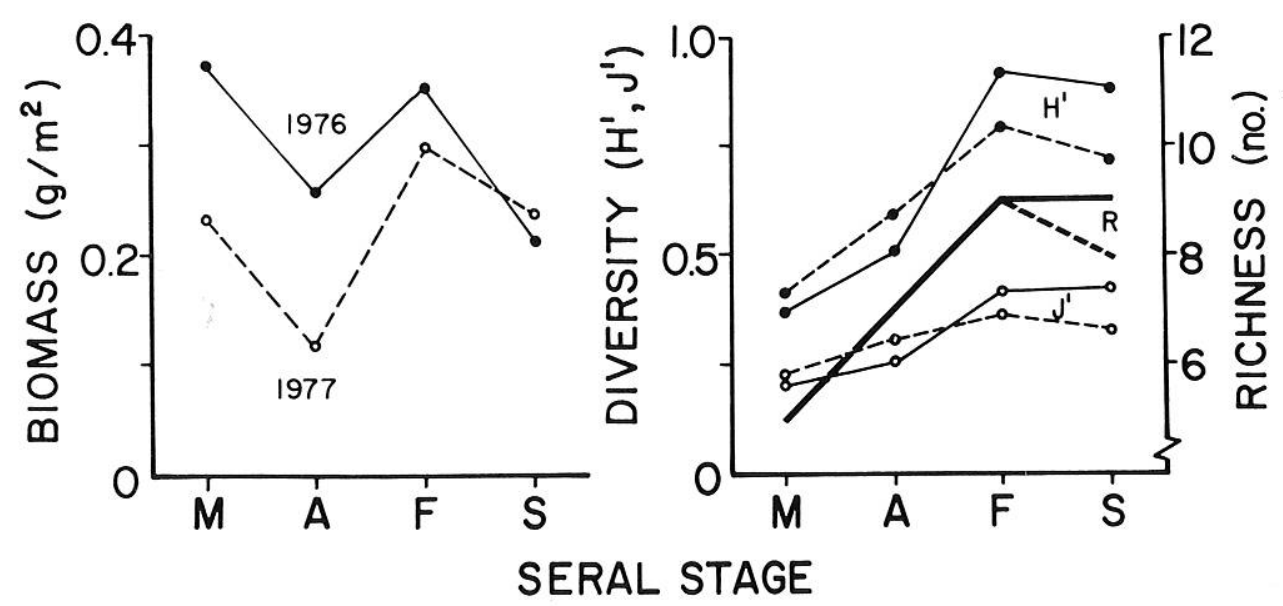

FIG. 4.-Changes in biomass, diversity, and species richness of herbivorous mammals between seral stages: (A) average daily biomass (standing crop) within each of the seral stages $\left(\mathrm{g} / \mathrm{m}^{2}\right) ;(\mathrm{B})$ general diversity is measured as the Shannon-Wiener index, $\mathrm{H}^{\prime}$ (closed circles), with equitability measured as J' (open circles), and species richness represented by the heavy line. Solid lines represent 1976, broken lines 1977 .

The ratio of secondary production to consumer standing crop, "P/B" as used here, is an index reflecting the efficiency of secondary production and/or the absolute amount of energy put into secondary production. Thus the greater either of these values, all else being equal, the higher the $\mathrm{P} / \mathrm{B}$ ratio should be. In this sense, the $\mathrm{P} / \mathrm{B}$ ratio is another indicator of the " $\mathrm{r}-\mathrm{K}$ " positioning of the overall community in terms of energy commitment. Our values of P/B (Fig. 3) follow the same trend as our $\mathrm{P} / \mathrm{R}$ ratios, thus adding support to the argument that early developmental stages are energetically dominated by species showing " $r$ " type life history characteristics.

TABLE 8.-Changes in population size estimates (\% of original value) used in examining effects of estimator error on energetics model output. Abbreviations of seral stages are as in Table 7.

\begin{tabular}{lcccccccc}
\hline & & \multicolumn{7}{c}{ Change in population estimate (\%) in trial } \\
\cline { 3 - 8 } \multicolumn{1}{c}{ Species } & Seral stage & 1 & 2 & 3 & 4 & 5 & 6 & 7 \\
\hline Thomomys & $\mathrm{M}$ & +10 & +5 & 0 & -5 & -10 & -15 & -10 \\
& $\mathrm{~A}$ & +50 & +30 & +10 & -10 & -30 & -50 & -30 \\
& $\mathrm{~F}$ & +140 & +90 & +40 & -10 & -50 & -100 & -50 \\
& $\mathrm{~S}$ & +300 & +220 & +140 & +60 & -20 & -100 & -20 \\
Lepus & $\mathrm{F}, \mathrm{S}$ & +20 & +12 & +4 & -4 & -12 & -20 & +12 \\
Tamiasciurus & $\mathrm{F}, \mathrm{S}$ & +20 & +12 & +4 & -4 & -12 & -20 & +12 \\
Peromyscus & $\mathrm{M}, \mathrm{A}, \mathrm{F}, \mathrm{S}$ & +100 & +80 & +60 & +40 & +20 & 0 & +20 \\
Tamias umbrinus & M,A,F,S & +100 & +80 & +60 & +40 & +20 & 0 & +20 \\
Tamias minimus & M,A,F,S & +100 & +80 & +60 & +40 & +20 & 0 & +20 \\
Glaucomys & $\mathrm{A}, \mathrm{F}, \mathrm{S}$ & +100 & +80 & +60 & +40 & +20 & 0 & +20 \\
\hline
\end{tabular}




\section{$P / R$}
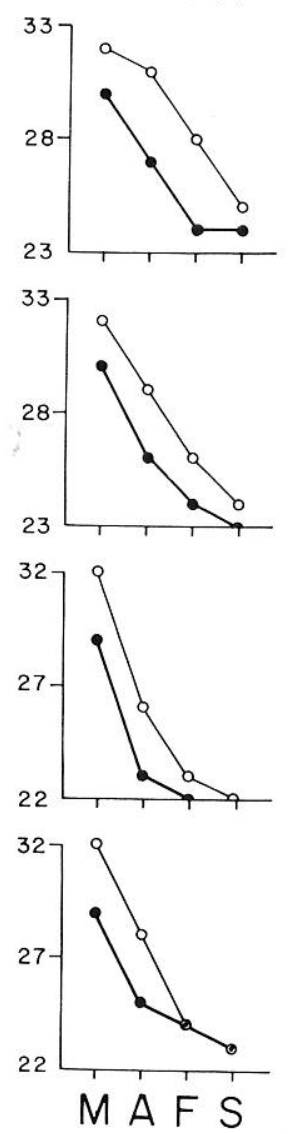
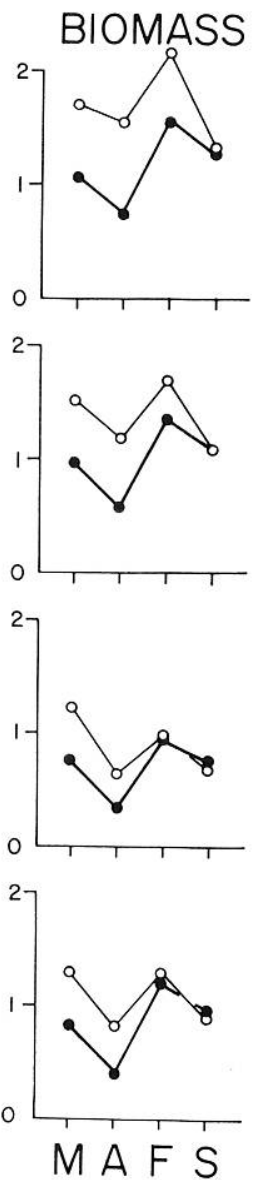

$B / E$
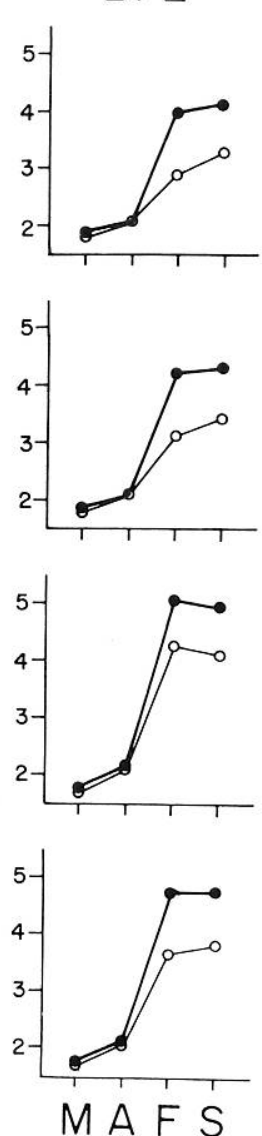

FIG. 5.-Effect of modification of population estimates on energy flow calculations. Results shown are from Trials 1, 3, 6, and 7 of Table 8. Abbreviations are as in Fig. 3. Units are $10^{-3}$ $\mathrm{g} / \mathrm{kcal}$ for P/R; $10^{2} \mathrm{~g} / \mathrm{m}$ for (total annual) biomass; $\mathrm{g} / \mathrm{kcal}$ for $\mathrm{B} / \mathrm{E}$.

Odum's prediction that the efficiency of biomass support (B/E) will increase during ecosystem development seems directly applicable to component taxocenes as well as to the ecosystem as a whole. The trends we observed (Fig. 3) support Odum's prediction. Our results also support Odum's prediction that production will be highest in the early seral stages (Fig. 3).

The herbivorous mammal component of the sere does not support Odum's prediction of increasing standing crop (biomass) with increasing ecosystem maturity (Fig. 4). Trends in diversity (Fig. 4) partially support Odum's prediction that both variety (species richness) and evenness will increase with increasing maturity. Both $\mathrm{H}^{\prime}$ (in both years) and J' (in 1976) reached highest values in the fir, however, suggesting that climax stages do not support maximum diversity.

Odum postulated that early succession should be characterized by small species while larger organisms should occupy the mature ecosystem. Although our results concerning this "life history" attribute are ambiguous, this postulate, like many of Odum's, may be inappropriate to address on the basis of a single taxocene (see 
TABLE 9.-Comparison of consumption, respiration, and production attributed to mammals in various communities.

\begin{tabular}{llcccl}
\hline & & \multicolumn{3}{c}{ Energy flow $\left(\mathrm{kcal} \mathrm{m}^{-2} \mathrm{yr}^{-1}\right)$} & \\
\cline { 3 - 5 } \multicolumn{1}{c}{$\begin{array}{c}\text { Seral } \\
\text { position }\end{array}$} & $\begin{array}{c}\text { Con- } \\
\text { sumption }\end{array}$ & $\begin{array}{c}\text { Respi- } \\
\text { ration }\end{array}$ & $\begin{array}{c}\text { Pro- } \\
\text { duction }\end{array}$ & \multicolumn{1}{c}{ Source } \\
\hline White spruce & Climax & 17 & 13 & 0.2 & Grodzinski, 1971 \\
Engelmann spruce $^{1}$ & Climax & 20 & 15 & 0.3 & This study \\
Montane meadow $^{2}$ & Early & 12 & 9 & 0.3 & This study \\
Tallgrass prairie & Climax & 20 & 13 & 0.3 & French et al., 1976 \\
\hline
\end{tabular}

${ }^{1}$ Lepus americanus and Erethizon dorsatum deleted from analysis.

${ }^{2}$ Thomomys talpoides and Erethizon dorsatum deleted from analysis.

MacMahon, in press). We note, however, that synthesizing data from disparate taxocenes is difficult, if possible at all in a meaningful way.

Although the quantitative aspects of energy flow along the successional gradient would be greatly affected by including the ungulates in the analyses, we feel the qualitative relationships among the seral stages, upon which our conclusions regarding Odum's attributes are based, would probably not be greatly modified. It is reasonable to assume that the bulk of summer forage consumption by deer and wapiti occurs in the meadow and aspen seral stages, which show the highest values of both production and diversity of herbaceous plant species. This assumption is supported by the results of studies that have investigated habitat use and forage consumption patterns of hand-reared deer and wapiti in montane forests elsewhere in the northern Rocky Mountains (deer-Wallmo et al., 1972; wapiti-Collins et al., 1978). Thus it is likely that only the relationship between the meadow and aspen seral stages might be changed in terms of dominance in biomass and energy flow parameters. The relatively large increase in biomass and hence energy flow that would in all likelihood be concentrated in the early seral stages would leave the major patterns of energy flow unchanged.

Several herbivorous mammal species were noted as ephemeral residents or transients within a seral stage. These included Marmota flaviventris and Spermophilus lateralis in the meadows, and Neotoma cinerea in aspen. Several regionally common species, notably Microtus montanus, were absent from the study area. The roles of these species in the structuring and functioning of the herbivorous mammal community under truly pristine conditions is unknown.

Community stability._Odum (1969, 1971:257) predicted an increase in overall homeostasis during ecosystem development (cf. Horn, 1974). In particular, resistance to external perturbation is expected to be low in early developmental stages and high in mature stages. The winter snowfall of 1976-77 was one of the lightest on record (Richardson, 1977), with late January depths in the School Forest averaging $\sim 30 \mathrm{~cm}$ in contrast to depths of $\sim 140 \mathrm{~cm}$ in $1975-76, \sim 180 \mathrm{~cm}$ in 1977-78, and comparable values in 1978-79. Meadows were free of snow by late April in 1977, 4 to 6 weeks earlier than usual. The combined effects of both the late arriving and light winter snowpack, and a relatively dry spring and early summer led to, in effect, a natural perturbation of the ecosystem under study.

Most small mammals within the study area were probably adversely affected by the absence of the normal insulative snowcover for much of the winter (see Formozov, 1946). The influence of the drought on plant phenology and productivity during the following growing season may have had an additional impact on most herbivorous mammal populations. In addition, the snowpack conditions may have been responsible for the large increase in the number of weasels (Mustela erminea and M. frenata) 
TABLE 10.-Ratios of total annual consumption $(C)$ and net aboveground primary production (NPP) within the four seral stages. Production estimates were calculated from information provided by N. West, S. Williams, and G. Zimmerman.

\begin{tabular}{|c|c|c|c|c|}
\hline & Meadow & Aspen & Fir & Spruce \\
\hline $\mathrm{NPP}\left(\mathrm{g} \mathrm{m}^{-2} \mathrm{yr}^{-1}\right)$ & 140 & 700 & 460 & 620 \\
\hline Consumption $^{1}\left(\mathrm{~g} \mathrm{~m}^{-2} \mathrm{yr}^{-1}\right)$ & 56 & 34 & 26 & 13 \\
\hline $\mathrm{C} / \mathrm{NPP}(\%)$ & $40^{2}$ & 5 & 6 & 2 \\
\hline
\end{tabular}

${ }^{1}$ Calculated from Table 7, 1976 data, assuming caloric content of vegetation to be $4.5 \mathrm{kcal} \mathrm{g}^{-1}$, and consumption by ungulates equals consumption by other species combined

${ }^{2}$ Excluding consumption due to Thomomys, $\mathrm{C} / \mathrm{NPP} \cong 4 \%$.

noted within the School Forest in 1977, perhaps by providing favorable conditions for reproduction and subsequent survival of young. More than 11 individuals were captured on the small rodent grids, and nine more were captured during the squirrel trapping sessions. Seven of the nine $M$. frenata caught in the Sherman traps were young. Previously no more than three weasels had been caught during summer trapping.

Assuming that normal environmental variability would produce only minor variation about the estimates of energy flow and biomass calculated for 1976, a comparison of the influence of the "perturbation" on the herbivorous mammal communities within the four seral stages can be made. Longer term data for Thomomys talpoides indicate that, at least for that species, the unusual combination of conditions experienced were indeed correlated with unusually low survivorship. Although there were large changes in the relative biomass of the individual species between 1976 and 1977 (Table 6), the total average daily biomass remained relatively constant in the more mature stages (Fig. 4). This pattern is evident also for community energy flow (Fig. 2). Thus, in terms of resistance to the combined effects of unusual physical and biotic environments, the herbivorous mammal community, as a unit, demonstrated greatest stability within the more mature successional stages.

Mammalian community energetics.-We have attempted to include all native mammalian herbivores present within the study area in our energetic analyses, and have been forced to exclude only the ungulates-mule deer and wapiti. Few studies concerned with community energetics of mammals are as comprehensive; the studies most comparable to ours are those of Grodzinski (1971) and French et al. (1976).

Grodzinski (1971) examined five species of small mammals resident in a climax Alaskan white spruce (Picea glauca) forest during a year in which population densities were considered to be near average. The study included two species common to our study area, Tamiasciurus (dominant in both areas) and Glaucomys, and two (as opposed to our four) ground-dwelling rodents. His study also included an insectivore, Sorex cinereus. Grodzinski's (1971) values for consumption, respiration, and production are comparable to our average values for climax Engelmann spruce forest when Lepus and Erethizon are ignored (Table 9). Of the six grassland small mammal communities examined by French et al. (1976), only the tallgrass prairie site, where five species including an insectivore were examined, produced values approaching those we found (Table 9).

Although montane meadow, the earliest seral stage we examined, is physiognomically closest to grassland, our meadow small mammal community (excluding Erethizon) consumed five times as much energy as did the tallgrass prairie community. This discrepancy may partially be the result of the exclusion of fossorial herbivores in the analyses of French et al. (1976). Exclusion of Thomomys from our analyses results in values (Table 9) below those for tallgrass prairie, but still considerably higher than those for short- or midgrass prairie, or for bunchgrass or desert grasslands. 
A.

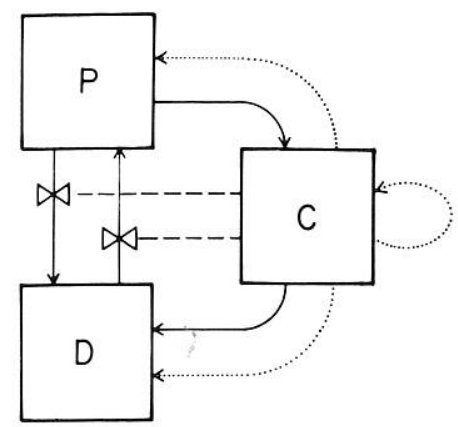

B.

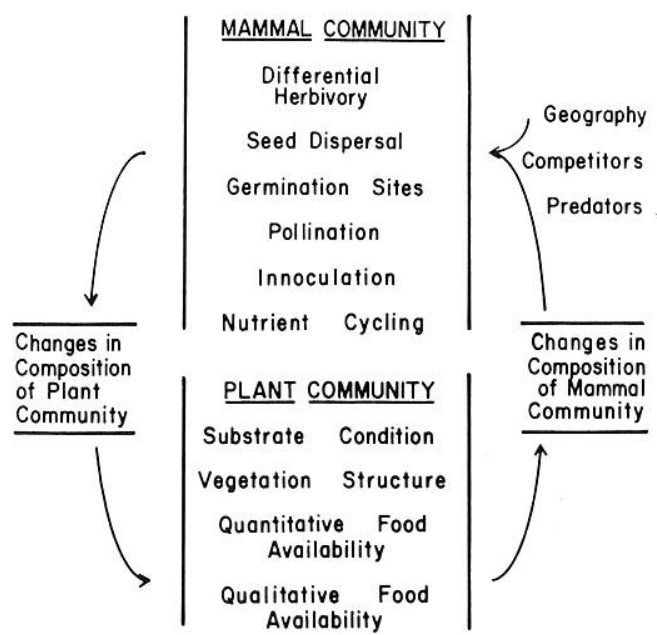

FIG. 6.-Biotic interactions affecting ecosystem structure and function. A is diagrammatic representation of the interactions between the generalized biotic components of an ecosystem. The boxes represent, in both qualitative and quantitative terms, the general state of the producer, consumer, and decomposer compartments (i.e., the kinds, distributions, abundances, rates of growth, etc., of their constituent organisms) and the solid lines represent flows of matter and/or energy. Dashed lines represent influences of consumer organisms on rates of direct exchanges between primary producers and decomposers, and dotted lines refer to influences of consumers on qualitative aspects of each compartment. B illustrates potential relationships between composition of the herbivorous mammal community and the composition of the plant community. Any tendency to cycle would lead to "succession" in both communities. Note that we do not include potential interactions between the mammals and the decomposer organisms, although we realize that such interactions may affect the successional process.

A serious problem in comparative community energetics is the variability among studies with regard to the proportion of the total community examined. The availability of a model such as that developed by French et al. (1976) and modified for use in this study provides the means necessary to examine in a more realistic and detailed manner the patterns of mammalian consumer energetics among different ecosystems. Such an analysis has been underway for some time among avian ecologists (e.g., Wiens, 1977 and references therein).

Mammals and succession.-The patterns of herbivorous mammal community energetics derived in this study support Odum's (1969) predictions, but the observed changes in some aspects of community structure do not. The underlying mechanism for Odum's postulated successional trends is most nearly approximated by the facilitation model of Connell and Slatyer (1977), a model not unlike that of Clements (1916) (see MacMahon, in press, for a review of concepts). The "role" of animals is not explicit in any successional model. While Odum (1971) specifically mentioned only birds, we infer that he (p. 259) considered mammals also to be more than “. . . entirely passive agents in the community ...."

The ratios of total consumption to aboveground production $(\mathrm{C} / \mathrm{P})$ within the four seral stages we examined were less than $10 \%$ in all but the earliest stage (Table 10). The value of $40 \%$ for meadow is probably artifactual; the large contribution of Thomomys, which relies heavily on belowground plant parts, to total consumption in the 
meadow (Table 7) points out the need to include belowground production estimates in calculating C/P ratios. A detailed analysis of the impact of Thomomys on energy flow in the sere is underway; we speculate that the inclusion of belowground production would reduce the $\mathrm{C} / \mathrm{P}$ ratio for the meadow by at least $1 / 2$.

Thus the importance of most consumers to the dynamics of communities or ecosystems must be one of affecting critical functions, rather than processing masses of energy (see also Chew, 1974, 1978; Lee and Inman, 1975). Figure 6A provides a general model of the way consumers affect other ecosystem components. Direct influences of consumers on producer and decomposer compartments through both consumptive and nonconsumptive impacts on transfers of matter and energy are well known. Influences that are less easily documented might include those that modify the species composition of the ecosystem or any of its trophic levels, i.e., positive or negative effects on particular taxa within the compartments. Thus, although consumers may regulate the form and amount of energy (organic matter) available to decomposers, they may also directly influence the species present in the decomposer compartment; e.g., via effects on soil $\mathrm{pH}$, aeration, and moisture content. The specific influence of herbivorous small mammals on ecosystem structure and function has been discussed and much of the literature reviewed by Golley (1973), Golley et al. (1975), Batzli (1975), Fleming (1975), Naumov (1975), and Chew (1974, 1978).

Virtually all studies concerning the mechanisms producing succession have been by workers dealing solely with plants. Connell and Slatyer (1977) pointed out this bias and suggested it was caused by the relatively large contribution of plants to the biomass and "structure" of ecosystems. These authors further pointed out that the largely ignored relationships between plants and herbivores may be of primary importance in determining succession, and suggested three alternative models to account for successional changes in "plants and sessile aquatic animals." The "facilitation" model includes animals as determinants of succession only insofar as they affect plant colonization. An alternative "inhibition" model is based in part on the eventual demise of early successional plant species through differential mortality, such as that which might be produced through quantitative or qualitative relationships with herbivores (Cates and Orians, 1975). The third, "tolerance" model again includes animals only insofar as they affect plant colonization. A partial list of the means by which mammals can affect plant distribution and abundance, and thus the rate and/or direction of succession, is given in Fig. $6 \mathrm{~B}$, together with some of the means by which the plant community can influence the mammalian community (see also Wagner, 1978). If a herbivore is closely tied to a particular plant species, then the distribution of the plant may determine the distribution of the herbivore (or vice versa, as discussed above). Correlations between the distributions of particular plant and mammal species have been noted in successional studies by Sly (1976). Such correlations may simply reflect independent responses to the same environmental gradient, e.g., soil moisture. No study, to our knowledge, has documented an obligatory relationship between an herbivorous mammal and an "early" successional plant species. More likely to have direct roles in determining the distributions of mammals along successional gradients are the particular suites of vegetation characteristics that provide the "food and cover" conditions necessary for each species' continued residency. In the case of small mammals, these characteristics may be largely reflected in plant physiognomy or architecture. Correlations between vegetation structure and the patterns of small mammal distribution and abundance have been noted in numerous studies, both along successional gradients and elsewhere (e.g., Wetzel, 1958; Pearson, 1959; M’Closkey, 1975; M'Closkey and Lajoie, 1975; Grant et al., 1977). The tendency for mammalian species diversity to be highest in mid-successional stages noted in this and other studies (e.g., Hirth, 1959; Kirkland, 1977; Roppe and Hein, 1978; Grodzinski, 1959; Hansson, 1978) 
may reflect the higher degree of structural complexity found in seral stages that include both early and late successional plant species.

The difficulties in elucidating any cause-and-effect relationship between an animal and a plant successional sequence are obvious. Few studies have unequivocally established a particular mammal as a major determinant of a successional pathway (but see Dunwiddie, 1977; Larrison, 1942; Snyder and Janke, 1976). It seems likely, however, that intensive synecological investigation of particular seres (e.g., Bédard et al., 1978) will indicate mammals to be something more than passive residents, as some workers (e.g., Laycock and Richardson, 1975; Pearson, 1959) have suggested. Future work toward elucidating the roles of mammalian herbivores in both developing and mature ecosystems will of necessity require experimental manipulation of the systems being examined.

A species' pattern of distribution and abundance may be influenced by a large number of factors, including vagility (and thus geography), the nature of interspecific competition, microclimatic conditions, food availability, nest sites, and the kinds or degree of protection afforded from predators. A universal relationship between the factors that affect a species' distribution and abundance, its role in succession, and its pattern of energy flow is unlikely. We suggest that the complete set of generalities in Table 1 will rarely be exemplified by the mammalian component of developing ecosystems, regardless of the mechanism producing the successional change.

\section{ACKNOWLEDGMENTS}

We thank the numerous individuals contributing to this project. D. Arnette, S. Montgomery, K. Lee, T. Radell, P. Fitzpatric, L. Becker, T. McCabe, and C. Winchell provided field assistance; the latter two also assisted in density determinations. Modification of the energetics model was greatly facilitated by B. Bayn. We are especially grateful to N. French and D. Swift for furnishing the copy of the original model. K. Smith, E. Zurcher, and T. McCabe made helpful comments on early drafts of the manuscript. Reviews by R. M. Chew, N. R. French, J. A. Gessaman, R. S. Hoffmann, R. T. M'Closkey, D. J. Schimpf and an anonymous reviewer aided in polishing and strengthening the final manuscript. This research was supported by N.S.F. Grant DEB 75-13996 to MacMahon.

\section{Literature Cited}

BAKER, R. J., AND S. L. Williams. 1972. A live trap for pocket gophers. J. Wildl. Mgmt., 36:1320-1322.

BAtZLI, G. O. 1975. The role of small mammals in arctic ecosystems. Pp. 243-268, in Small mammals: their productivity and population dynamics (F. B. Golley, K. Petrusewicz, and L. Ryszkowski, eds.). Cambridge Univ. Press, 451 pp.

BÉdARD, J., M. CRÊTE, AND E. AUdy. 1978. Short-term influence of moose upon woody plants of an early seral wintering site in Gaspé Peninsula, Quebec. Canadian J. Forestry Res., 8:407-415.

Burnham, K. P., And W. S. Overton. 1969. A simulation study of live-trapping and estimation of population size. Dept. Stat., Tech. Rept., Oregon State Univ., 14:1-60.

Cates, R. G., and G. H. Orians. 1975. Successional status and the palatability of plants to generalized herbivores. Ecology, $56: 410-418$

Chew, R. M. 1974. Consumers as regulators of ecosystems: an alternative to energetics. Ohio J. Sci., 74:359-370.

- 1978. The impact of small mammals on ecosystem structure and function. Pp. 167-180, in Populations of small mammals under natural conditions (D. P. Snyder, ed.), Spec. Pub. Ser. Pymatuning Lab. Ecol., Univ. Pittsburgh, 5:1-237.

Clements, F. E. 1916. Plant succession: an analysis of the development of vegetation. Publ. Carnegie Inst., Washington, 242:1512.

Collins, W. B., P. J. Urness, And D. B. AusTIN. 1978. Elk diets and activities on different lodgepole pine habitat segments. J. Wildl. Mgmt., 42:799-810.

Connell, J. H., and R. O. Slatyer. 1977. Mechanisms of succession in natural communities and their role in community stability and organization. Amer. Nat., 111:11191144.

Dolbeer, R. A., AND W. R. Clark. 1975. Population ecology of snowshoe hares in the 
central Rocky Mountains. J. Wildl. Mgmt., 39:535-549.

Drury, W. H., AND I. C. T. Nisbet. 1973. Succession. J. Arnold Arboretum, 54:331368.

DUNwiddie, P. W. 1977. Recent tree invasion of subalpine meadows in the Wind River Mountains, Wyoming. Arctic Alp. Res., 9:393-399.

EbERHARDT, L. L. 1978. Transect methods for population studies. J. Wildl. Mgmt., 42:1-31.

FLEMING, T. H. 1975. The role of small mammals in tropical ecosystems. Pp. 269-298 in Small mammals: their productivity and population dynamics (F. B. Golley, K. Petrusewicz, and L. Ryszkowski, eds.). Cambridge Univ. Press, 451 pp.

Formozov, A. N. 1946. Snow cover as an integral factor of the environment and its importance in the ecology of mammals and birds. (English edition) Occas. Paper Boreal Inst. Northern Studies, Univ. Alberta, Alberta, Canada, 1:1-141.

French, N. R., W. E. Grant, W. Grodzinski, AND D. M. SWIFT. 1976. Small mammal energetics in grassland ecosystems. Ecol. Monogr., 46:201-220.

GetTingeR, R. D. 1975. Metabolism and thermoregulation of a fossorial rodent, the northern pocket gopher (Thomomys talpoides). Physiol. Zool., 48:311-322.

Golley, F. B. 1973. Impact of small mammals on primary production. Pp. 142-147 in Ecological energetics of homeotherms (J. A. Gessaman, ed.). Monogr. Series, Utah State Univ. Press, Logan, 20:1-155.

Golley, F. B., L. Ryszkowski, AND J. T. SoKUR. 1975. The role of small mammals in temperate forests, grasslands and cultivated fields. Pp. 223-241, in Small mammals: their productivity and population dynamics (F. B. Golley, K. Petrusewicz, and L. Ryszkowski, eds.). Internatl. Biol. Programme, Cambridge Univ. Press, 5:1-451.

Grant, W. E., N. R. FrenCH, AND D. M. SWIFT. 1977. Response of a small mammal community to water and nitrogen treatments in a shortgrass prairie ecosystem. J. Mamm., 58:637-652.

Grodzinski, W. 1959. The succession of small mammal communities on an overgrown clearing and landslip mountain in the Beskid Sredni (Western Carpathians). Ekol. Polska, 7:83-143.

- 1966. Bioenergetics of small mammals from Alaskan taiga forest. Lynx, 6:51-55.

- 1971. Energy flow through populations of small mammals in the Alaskan taiga forest. Acta Theriol., 16:231-275.

HANSEN, L. P., AND J. E. WARNOCK. 1978. Response of two species of Peromyscus to vegetational succession on land strip-mined for coal. Amer. Midland Nat., 100:416-423.
Hansson, L. 1978. Small mammal abundance in relation to environmental variables in three Swedish forest phases. Studia Forestalia Suecica, 147:1-40.

Hart, J. S., H. Pohl, and J. S. Tener. 1965. Seasonal acclimatization in varying hare (Lepus americanus). Canadian J. Zool., 43:731-744.

Hirth, H. F. 1959. Small mammals in old field succession. Ecology, 40:417-425.

Holter, J. B., G. Tyler, and T. Walski. 1974. Nutrition of the snowshoe hare (Lepus americanus). Canadian J. Zool., 52:15531558.

HoRN, H. S. 1974. The ecology of secondary succession. Ann. Rev. Ecol. Syst., 5:25-37.

Humphreys, W. F. 1979. Production and respiration in animal populations. J. Anim. Ecol., 48:427-453.

Irving, L., H. Krog, AND M. Monson. 1955. The metabolism of some Alaskan animals in winter and summer. Physiol. Zool., 28:173185.

JENNRICH, R. I., AND F. B. TURner. 1969. Measurement of non-circular home range. J. Theor. Biol., 22:227-237.

KeLKeR, G. H. 1945. Measurement and interpretation of forces that determine populations of managed deer. Unpubl. Ph.D. dissert., Univ. Michigan, Ann Arbor, 422 pp.

Kemp, G. A., AND L. B. KeITH. 1970. Dynamics and regulation of red squirrel (Tamiasciurus hudsonicus) populations. Ecology, 51:763-779.

KirKLAND, G. L., JR. 1977. Responses of small mammals to the clear cutting of northern Appalachian forests. J. Mamm., 58:600-609.

KLeiber, M. 1961. The fire of life. John Wiley and Sons, New York, 454 pp.

Krefting, L. W., ANd C. E. Ahlgren. 1974. Small mammals and vegetation changes after fire in a mixed conifer-hardwood forest. Ecology, 55: 1391-1398.

LARrison, E. J. 1942. Pocket gophers and ecological succession in the Wenas region of Washington. Murrelet, 23:34-41.

LAYCOCK, W. A., AND B. Z. RICHARDSON. 1975. Long-term effects of pocket gopher control on vegetation and soils of a subalpine grassland. J. Range Mgmt., 28:458-462.

LEE, J. J., AND D. L. Inman. 1975. The ecological role of consumers-an aggregated systems view. Ecology, 56:1455-1458.

LEVINS, R. 1966. The strategy of model building in population biology. Amer. Sci., $54: 421-431$

MacMahon, J. A. in press. Ecosystems over time: succession and other types of change in ecosystems. In Forests: fresh perspectives from ecosystem analysis (R. Waring, ed.). Proc. 40th Ann. Biol. Colloquium, Oregon St. Univ. Press, Corvallis.

Macmahon, J. A., D. L. Phillips, J. V. RoB- 
INSON, AND D. J. SCHIMPF. 1978. Levels of biological organization: an organism-centered approach. BioScience, 28:700-704.

M'Closkey, R. T. 1975. Habitat succession and rodent distribution. J. Mamm., 56:950955.

M'Closkey, R. T., And D. T. Lajoie. 1975. Determinants of local distribution and abundance in white-footed mice. Ecology, 56:467472.

Nadler, C. F., R. S. Hoffmann, J. H. HonACKI, AND D. Pozini. 1977. Chromosomal evolution in chipmunks, with special emphasis on A and B karyotypes of the subgenus Neotamias. Amer. Midland Nat., 98:343353.

NaUmov, N. P. 1975. The role of rodents in ecosystems of the northern deserts of Eurasia. Pp. 299-309, in Small mammals: their productivity and population dynamics (F. B. Golley, K. Petrusewicz, and L. Ryzskowski, eds.). Internatl. Biol. Programme, Cambridge Univ. Press, 5:1-451.

ODum, E. P. 1969. The strategy of ecosystem development. Science, 164:262-270.

- 1971. Fundamentals of ecology. Third ed. W. B. Saunders, Philadelphia, 574 pp.

Pearson, P. G. 1959. Small mammals and old field succession on the Piedmont of New Jersey. Ecology, 40:249-255.

Richardson, E. A. 1977. Drought update for the week ending August 5, 1977. Utah Sci., 38:93-95.

Roppe, J. A., ANd D. Hein. 1978. Effects of fire on wildlife in a lodgepole pine forest. Southwestern Nat., 23:279-288.

Rusch, D. A., AND W. G. Reeder. 1978. Population ecology of Alberta red squirrels. Ecology, 59:400-420.

Schimpf, D. J., J. A. Henderson, And J. A. MacMahon. In press. Some aspects of succession in the spruce-fir zone of northern Utah. Great Basin Nat.

SLy, G. R. 1976. Small mammal succession on strip-mined land in Vigo County, Indiana. Amer. Midland Nat., 95:257-267.

Sмiтh, G. W. 1977. Population characteristics of the porcupine in northeastern Oregon. J. Mamm., 58:674-676.

SNydER, J. D., AND R. A. Janke. 1976. Impact of moose browsing on boreal-type forests of Isle Royale National Park. Amer. Midland Nat., 95:79-92.

TAYLOR, W. P. 1935. Ecology and life history of the porcupine (Erethizon epixanthum) as related to the forests of Arizona and the southwestern United States. Univ. Arizona Bull., 6:1-177.

Utah Division of Wildlife Resources, 1977. Utah big game investigations and management recommendations. UDWR Publ. No. 77-5.

Verts, B. J. 1957. The population and distribution of two species of Peromyscus on some Illinois strip-mined land. J. Mamm., 38:53-59.

WAGNER, F. H. 1978. Some concepts in the management and control of small mammal populations. Pp. 192-202, in Populations of small mammals under natural conditions (D. P. Snyder, ed.). Spec. Publ. Ser., Pymatuning Lab. Ecol., Univ. Pittsburgh, 5:1-237.

Wallmo, O. C., W. L. Regelin, and D. W. REICHERT. 1972. Forage use by mule deer relative to logging in Colorado. J. Wildl. Mgmt., 36:1025-1033.

Wetzel, R. M. 1958. Mammalian succession on midwestern floodplains. Ecology, 39:262271.

WIEns, J. A. 1977. Model estimation of energy flow in North American grassland bird communities. Oecologia, 31:135-151.

Wiens, J. A., AND G. S. InNis. 1974. Estimation of energy flow in bird communities: a population bioenergetics model. Ecology, 55:730-746.

Woods, C. A. 1973. Erethizon dorsatum. Mamm. Species, 29:1-6.

Department of Biology and the Ecology Center (DCA and JAM) UMC 53, and Department of Wildlife Science (MLW) UMC 52, Utah State University, Logan, UT 84322. Submitted 12 July 1979. Accepted 26 December 1979. 
